\title{
The Teaching Mode Exploration of the Innovative Practice for Agriculture Machinery Specialty from the Perspective of Ideological and Political Education in Professional Courses
}

\author{
Xin Song \\ College of Engineering and Technology \\ Tianjin Agricultural University \\ Tianjin, China \\ songxin-tju@163.com \\ Yule Liu \\ College of Engineering and Technology \\ Tianjin Agricultural University \\ Tianjin, China \\ 495757775@qq.com
}

\author{
Yun Han* \\ College of Engineering and Technology \\ Tianjin Agricultural University \\ Tianjin, China \\ $396051786 @ q q . c o m$ \\ Jianbo Liu \\ College of Engineering and Technology \\ Tianjin Agricultural University \\ Tianjin, China \\ 764282636@qq.com
}

\begin{abstract}
According to the problem of emphasizing on intellectual development and ignorant of ideological and political education in innovative practice teaching in our department, the new innovative practice teaching mode has been tentative explored for agriculture machinery specialty from the perspective of ideological and political education in professional courses. Then the key links have been defined such as: the establishment of teaching targets; the design of teaching activities; the excavation and definition of ideological and political education elements in professional courses; the organic integration of the elements in innovative practice; the improvement of teacher's subjective consciousness of ideological and political education in professional courses; the improvement of teacher's education skills. Based on the above facts, the innovative practice teaching mode for agriculture machinery specialty has been realized and applied from the perspective of ideological and political education in professional courses.
\end{abstract}

Keywords-ideological and political education in professional courses; agriculture machinery specialty; innovative practice; teaching mode

\section{INTRODUCTION}

In 2016, in the national colleges ideological and political work conference, the General Secretary $\mathrm{Xi}$ Jinping has emphasized that the morality and nurturing should be made as the central link, the ideological and political education should be throughout the whole education and teaching process, and the whole process education and all-round education for students should be realized. It is necessary to take full advantage of class teaching as the main channel to associate all kinds of courses with ideological and political theory courses to generate synergistic effect ${ }^{[1]}$.

The research was sponsored by the education and teaching reform project of Tianjin Agricultural University (2018-C-09).
Under the new situation, it is the great subject for ideological and political education to implement the General Secretary Xi Jinping's speech and realize the purpose of the whole process education and all-round education by cooperating the professional teachers with the ideological and political teachers in the current colleges and universities. The innovation of ideological and political education has been put forward entirely in professional courses in Shanghai in 2017. The ideological and political theory course is constructed as the core, and the comprehensive quality course is constructed as the support, and the professional education course is constructed as the radiation in the course system of ideological and political education ${ }^{[2]}$. All that are made as the important channel for developing the education function in all curriculums, and for implementing the teacher's duty, which would make the professional curriculum come along with the ideological and political curriculum, so that the synergistic effect has been generated.

In 2017, in order to further implement the spirit of the 19 th National Congress of the Communist Party of China and the spirit of the ideological and political conference for colleges and universities, The implement outline for improving the quality of ideological and political work in colleges and universities has been published by the Ministry of Education. It is clearly proposed that education should be promoted balanced, and the innovation should be promoted vigorously which aims at ideological and political education in professional courses. The ideological and political elements should be defined in every professional course and the education function. Then the elements should be integrated into the class teaching. At last, the ideological and political education should be organic integrated with the knowledge education. 
The innovative idea of the ideological and political education in professional courses is different to the education target: "Reorganization, Emotion and Skill" which is proposed by the Bloom ${ }^{[3]}$ in 1956 in America, and is also different to the dominant education of the ideological and political theoretical courses in colleges and universities. Because the ideological and political education is emphasized on the moral education resources, and it is put in the first place in the Educational Planning. Then it is collaborated with the professional education, which leads us the development direction.

Recently, in order to closely combine the social needs and discipline development, the talent cultivation mode of "theory teaching, practice innovation and scientific research”, which is a trinity, is constructed in the department of mechanical engineering by constantly exploring the teaching reform in agricultural mechanization and automation. It aims at improving the ability and quality of talents. In particularly, in order to highlight the school-running characteristics of "emphasis on practice and strong ability", the professional tutorial system is established and the practice teaching system is implemented which is used to integrate inside and outside classroom communication. And in practical teaching, the vocational qualification certification and the general simulation training are integrated and the students' personality development is emphasized. Hence the students are encouraged to participate in various types of innovation competition and teacher's scientific research project for improving the experiment skill and the engineering practical ability. By far, more than $75 \%$ students have actively participated in the various innovative practices and scientific research projects.

Although the engineering practice ability and integrated innovation consciousness for the students in the college of engineering and technology has been improved in high degree by the teaching mode of "theory teaching, practice innovate, science research" which is trinity. In general, there are still the problems which focus on intellectual development, and the problems which ignore ideological and political education. At the same time the cultivating mode, the education design and method are also emphasized on acquiring professional knowledge, improving the ability of analysis and solving practical problem. However the humanity quality, ideal, faith and the guidance and inspiration on value level are weaken.

Aim at this problem, the teaching mode exploration of the innovative practice, which is used for agriculture machinery specialty from the perspective of ideological and political education in professional courses, is proposed in the paper. The practice teaching method is innovated, meanwhile the engineering practice resources are transformed into moral education resources, and are paid attention to from the student $\mathrm{s}^{\prime}$ specialty training to their spiritual world training. Sequentially, the problem that professional education segregates the ideological and political education, which has existed for a long time, has been broken through. By the method, the students would be guided to be patriotic, truthseeking, inspirational and practical. The collaborative development between the knowledge imparting and values leading would be realized too. At last the education quality has been improved further..
II. The CONSTRUCTION IDEA OF INNOVATIVE PRACTICAL TEACHING MODE OF AGRICULTURAL MACHINERY SPECIALTY FROM THE PERSPECTIVE OF IDEOLOGICAL AND POLITICAL EDUCATION IN PROFESSIONAL COURSES

\section{A. Establish the teaching targets}

The innovative practice targets are established by associating the need for the industrial and technological progress, local and regional economy development which is especially for the development of the high-tech intelligent agricultural machinery equipment industry. When the targets are established accompanied with the features of the ideological and political education emphasized on associating with the intellectual development, the problem of educating person for who and educating what kind of person is solved

1) Professional ability and accomplishment

Professional ability: By using the former teaching mode of "theory teaching, practice innovate, science research" which is trinity, the need for agricultural machinery equipment development and talent skill are satisfied combing with the practice theme of part measuring, CAE, and the key components design of agricultural machinery equipment. So the college students would be acquaint with the research progress in engineering project and the whole process of CAD and CAE components and parts in practice teaching. Then the learning professional knowledge would be used in the practical case to deepen understanding.

Professional accomplishment: By the practical training for engineering case, the ability of learning profession and the future vacation, and defining the career orientation would be identified by the college students. Then the dedication and craftsmanship is trained, and the professional quality which includes unity, cooperation, responsibility and integrity etc. is reflected in the practice education evaluation system.

\section{2) Research ability and scientific literacy}

Research ability: By innovative practice, the knowledge and even multiply knowledge to achieve the synthetic project practice associated with the division of cooperation would be used by the college students. Hence the ability of finding and solving problems, reviewing literature, summary, experiment design, organization implementation, and scientific expression has been trained and improved.

Scientific literacy: During the period of target implement, the logical thinking and creativity has been trained. And the ability to study, analyze and solve problems independently has been trained, which embodies the science spirit of rigorous and the seeking truth from facts.

\section{B. The design of innovative practice teaching}

Follow by the teaching circulation processes: "teaching target-teaching activity-teaching evaluation-teaching target”, the teaching activity model, which is emphasized on the college students participatory interaction and feedback, is constructed by the innovative practice teaching design. And the elements of the ideological and political education are effective merged based on the model ${ }^{[4-5]}$ 
The specific teaching process is classified six procedures by the teaching activity model, as shown in Fig. 1.

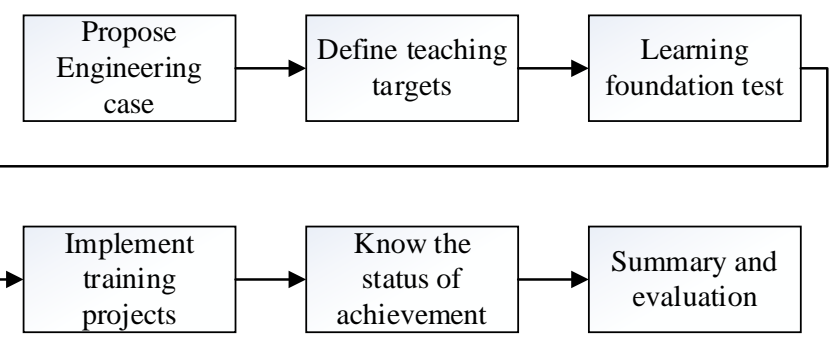

Fig. 1. Teaching activity model

Step 1: The engineering case is proposed by the teacher, and then the theme background in engineering is used to arouse the college students' enthusiasm;

Step 2: The problems from the engineering case are provided according to the teaching targets, which make students think deeply;

Step 3: The students' learning foundation concerned with teaching targets is tested. And the case analysis of the practical training project is carried on;

Step 4: By participatory learning, the students are guided to complete the project and the practical problem for exercising the college students engineering thinking step by step;

Step 5: The students' achievement of teaching objectives through engineering practice training are understood;

Step 6: Summary and evaluation.

The core advantage of the teaching activity model is that it emphasizes students to participate in learning in an all-round way rather than simply listen to the teachers. In addition, it can timely feedback the learning effect in the training process, so that the learning effect can be timely understood and the students are guided to complete the training targets better.

\section{Extracting the ideological and political education elements}

According to the six procedures of innovative practice teaching, the ideological and political education elements are excavated and defined by the professional identity, professional ethics, social responsibility, socialist core values and excellent traditional Chinese cultural education etc. The simplicity knowledge system constrain is broken through, and the dominant professional knowledge education is deeply integrated with recessive values education and the sublimate value system. Then the professional theme is converted to the knowledge of virtue. Hence the students are guided to correctly understand the development trend of the world and China, correctly understand Chinese characteristics and make international comparisons, and correctly understand the responsibilities and historical missions of the times, and have lofty aspirations and down-to-earth attitude. Then the college students would be a ability and political integrity talent when the conviction is strengthened; the determination and ability for solving the practical problems is enhanced; the students are guided to be firm believers, active disseminators and model practitioners of socialist core values.

\section{The integration of ideological and political elements in innovative practical teaching}

Guided by the teaching targets, the teaching targets are disintegrated, and the ideological and political education elements are excavated and defined in the teaching links and knowledge points. Then the extracted elements are organically integrated into the teaching process which combine theory with practice, history with reality, dominant education with recessive education, generality with individuality, and positive education with discipline. In fact, the ideological and political education elements are closely connected with the education content for giving full expression in teaching targets. Each teaching link, which integrates with the ideological and political education elements, should be used to make the related evaluation methods to assessment and feedback. For example, in the link of proposing engineering case and defining teaching objectives, the students are guided to correctly understand the development trend of the world and our country, correctly understand the responsibility of the times and historical mission. Then the students are guided to strengthen their determination and confidence to solve practical problems by introducing the background of the questions raised, the research status of relevant technologies at home and abroad, and the professional skills that agricultural machinery major students must possess in the face of the future development trend and so on. In the implementation of the practical training project, the correct concept of occupation, craftsman spirit, social responsibility, innovative spirit and other ideological and political elements can be introduced timely, so that the students' professional awareness and ability, social responsibility and ability, practical awareness and ability, as well as the innovative awareness and ability can be effectively cultivated and improved.

Realizing the organic integration of engineering practical training associated with "the unity of knowledge and practice" and ideological and political connotation is an effective means to break through the dilemma of "two skins" phenomenon between professional course teaching and ideological and political education. Then the problem that how to cultivate people, and how to achieve the goal of all-round and wholeprocess education would be solved

\section{E. The improvement of teacher's subjective consciousness of ideological and political education in professional courses and education skills}

The curriculum teaching is the main channel and core link in implement ideological and political education. Because the college teachers are the bosom friends and mentors for the students in the healthy growth, and are the main power in implement ideological and political education in professional courses. In order to establish the big ideological and political structure, the teacher's subjective consciousness of ideological and political education in professional courses and the education skills should be improved as the important focus and entry point for integrating ideological and political education into professional courses. Firstly, the ideological 
and political education and the construction of ethics, moral cultivation should be constantly strengthened by professional teachers. Then morality, nurturing and practicing the core socialist values into teaching and academic research should be made. Secondly, it is necessary to constantly update knowledge structure, timely track the development trend and advanced technology of the major, and keep the teaching content up to date. Finally, how to use emotion, professional knowledge and life experience to realize the all-round and whole-process education should be thought deeply from three aspects which are class teaching, extracurricular practice and humanistic care respectively.

\section{CONCLUSION}

Under the new situation, "Ideological and political education in professional courses" is the effective carrier to improve the college students' education in ideological and political $^{[6]}$. According to the problem of emphasizing on intellectual development and ignorant ideological and political education in innovative practice teaching in our department, the innovative practice teaching mode has been tentative explored for the major of agriculture machinery from the perspective of ideological and political education in professional courses. And the construction idea with its key points in the teaching mode has been defined.

In future, the ideological and political education elements would be excavated and defined in innovative practice teaching. Then the method and strategy would be explored for the organic integration of ideological and political elements with innovative practical teaching. At last the construction of innovative practice teaching mode would be realized in the major of agriculture machinery from the perspective of ideological and political education.

\section{ACKNOWLEDGMENT}

In this paper, the research was sponsored by the education and teaching reform project of Tianjin Agricultural University (2018-C-09).

\section{REFERENCES}

[1] J.P. Xi, "The important speech at the national college conference of ideological and political work,” People's Daily, December 2016.(In Chinese)

[2] W. Jiao, Z.T. Chen, and L.J. Li, "The colleges and universities in Shanghai are actively investigating the reform of ideological and political education,” Shanghai education, vol.19, pp. 8-9, June 2017. (In Chinese)

[3] H.Y. Wu. "A review on bloom's taxonomy of cognitive educational objectives-focus on bloom's views of knowledge and ability,” Journal of Suzhou university of science and technology (Social Science), vol.28, pp.86-90, March 2011. (In Chinese)

[4] H. Mu, C. Li. "BOPPPS model and its application in research education,” Shanxi education (High-education), vol.10, pp27-30, October 2015. (In Chinese)

[5] L. Huang, X.Q. Yu. "The Practice of BOPPPS teaching model combined with rain class in surveying and mapping technology and professional introduction course," Education teaching forum,vol.13,pp. 139-141, April 2019. (In Chinese)

[6] Q. Zhang. "The design and implementation of innovative practical course in ideological and political education," The western quality education, vol.4, pp. 188, June 2018. (In Chinese) 